\title{
Matricellular Protein Periostin Contributes to Hepatic Inflammation and Fibrosis
}

Yangmei Huang, ${ }^{*}$ Weiping Liu, ${ }^{*}$ Hongjun Xiao, ${ }^{*}$ Alaiyi Maitikabili, ${ }^{*}$ Qinghua Lin, ${ }^{\dagger}$ Tiantian Wu, ${ }^{*}$ Zhengjie Huang, ${ }^{\ddagger}$ Fan Liu, ${ }^{\S}$ Qi Luo, and Gaoliang Ouyang*

From the State Key Laboratory of Cellular Stress Biology, * Innovation Center for Cell Signaling Network, School of Life Sciences, Xiamen University, Xiamen; the Clinical Laboratory, ${ }^{\dagger}$ Xiamen Hospital of Traditional Chinese Medicine, Xiamen; the Department of Surgical Oncology, ${ }^{\ddagger}$ First Affiliated Hospital of Xiamen University, Xiamen; and the Medical College, ${ }^{\S}$ Xiamen University, Xiamen, China

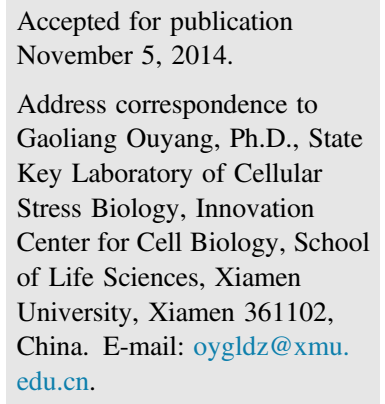

\begin{abstract}
Periostin actively contributes to tissue injury, fibrosis, atherosclerosis, and inflammatory diseases; however, its role in hepatic fibrosis is unclear. Herein, we revealed that periostin expression was significantly up-regulated in carbon tetrachloride- and bile duct ligation-induced mice with acute and chronic liver fibrosis. Deficiency in periostin abrogated the development of liver fibrosis in mice. Carbon tetrachloride treatment significantly increased $\alpha$-smooth muscle actin, fibronectin, and collagen I levels in wild-type mice, which were unaffected in periostin-knockout mice. Periostin-deficient mice showed a significantly reduced area of collagen deposition and decreased levels of serum alanine aminotransferase and aspartate aminotransferase compared with wild-type mice after 2 weeks of carbon tetrachloride administration. Chemokine ligand 2, IL-6, IL-1 $\beta$, tumor necrosis factor- $\alpha$, and tissue inhibitor of metalloproteinases $1 \mathrm{mRNA}$ levels were significantly lower in periostin-deficient mice than in wild-type mice after carbon tetrachloride treatment. Periostin colocalized with hepatic stellate cell-derived collagen I and $\alpha$-smooth muscle actin in mouse acute and chronic fibrotic liver tissues. Transforming growth factor (TGF)- $\beta 1$ markedly induced periostin expression in primary mouse hepatic stellate cells. Periostindeficient mice showed significantly lower levels of TGF- $\beta 1$ and TGF- $\beta 2$ compared with wild-type mice after carbon tetrachloride treatment. High levels of periostin in patients with acute or chronic hepatitis correlated with TGF- $\beta 1$ and TGF- $\beta 2$ expression in serum from patients with hepatitis. Data indicate that periostin is a novel mediator of hepatic fibrosis development. (Am J Pathol 2015, 185: 786-797; http:// $d x . d o i . o r g / 10.1016 / j$.ajpath.2014.11.002)
\end{abstract}

Liver fibrosis is a common consequence of chronic liver damage, such as damage due to hepatotropic viruses (mainly hepatitis B and C viruses), toxins, excessive alcohol intake, and autoimmunity. Liver fibrosis is characterized by alteration of tissue architecture and deposition of collagenrich extracellular matrix (ECM). Chronic inflammatory stimuli can cause hepatocyte death, and the apoptotic hepatocytes, in turn, stimulate the hepatic resident macrophages (ie, Kupffer cells) and the recruited inflammatory leukocytes to secrete proinflammatory cytokines and profibrogenic factors, which activate collagen-producing hepatic stellate cells (HSCs). These immunological and tissue repair responses result in excessive collagen deposition and compromised liver function. ${ }^{1-3}$ HSCs are a major source of ECM proteins in the damaged liver. Under physiological conditions, HSCs maintain a quiescent phenotype. After liver injury, the quiescent HSCs can be activated by several fibrogenic stimuli, including transforming growth factor $\beta$ (TGF- $\beta$ ), platelet-derived growth factor, and inflammatory cytokines that are mainly secreted by Kupffer cells. The activated HSCs transdifferentiate into

\footnotetext{
Supported by National Nature Science Foundation of China grants 81372841, 31171339, 31071302, and J1310027/J0106, the Programme of Introducing Talents of Discipline to Universities grant B12001, the 111 Project of Education of China grant B06016, the Fundamental Research Funds for the Central Universities, the Program for New Century Excellent Talents in University grant NCET-11-0296, and the Scientific Fund for Distinguished Young Investigator of Fujian Province grant 2010J06013.

Y.H., W.L., and H.X. contributed equally to this work.

Disclosures: None declared.
} 
myofibroblasts and produce excessive ECM proteins, which result in excessive collagen deposition and subsequent liver fibrosis. ${ }^{1-3}$

Matricellular proteins are a family of secreted ECM proteins that includes osteopontin (OPN), tenascins, cysteine-rich acidic secreted protein (SPARC), CCNs, thrombospondins, and periostin. These non-structural ECM proteins are important during embryonic development but are typically restricted to tissue remodeling and wound repair in the normal adults. ${ }^{4-6}$ Periostin (encoded by Postn) was originally identified in MC3T3-E1 osteoblast cells as a critical regulator of bone and tooth development and maintenance. ${ }^{7,8}$ Periostin is mainly expressed in collagen-rich fibrous connective tissues, including heart valves, tendons, corneas, the perichondrium, and the periodontal ligament, which are subjected to constant mechanical stresses during embryonic development or pathogenesis. ${ }^{9-11}$ Current evidence in animal models and patients demonstrates that periostin is also involved in the pathobiology of various inflammatory diseases, including tissue injury, fibrosis, arthritis, atherosclerosis, and other inflammatory diseases. ${ }^{12-16}$ Periostin is a critical mediator of the healing process of myocardial infarction, ${ }^{17,18}$ and plays a critical role in fibrosis of bronchial asthma and chronic allergic skin inflammation. ${ }^{13,19}$ Periostin-deficient mice show a reduction in pulmonary fibrosis. ${ }^{14}$ Interestingly, as a critical developmental factor and a secreted ECM protein, periostin is also overexpressed in various types of human cancers and contributes to tumorigenesis and metastasis. ${ }^{5,20-23}$ Collectively, these findings suggest that periostin actively contributes to tissue injury, inflammation, fibrosis, and tumor initiation and progression. ${ }^{15,24}$ Interestingly, a recent report reveals that periostin actively contributes to obesity-induced hepatosteatosis. ${ }^{25}$ However, whether periostin is involved in liver fibrosis progression has not yet been studied. $^{26}$

Our aim was to explore the role of periostin in liver fibrosis. Herein, by using murine experimental models of liver fibrosis, we demonstrate that periostin is up-regulated in carbon tetrachloride - and bile duct ligation (BDL)-induced acute and chronic liver fibrosis and that liver fibrosis is dramatically decreased in periostin-deficient mice. The level of periostin is significantly elevated in the serum of patients with acute or chronic hepatitis. We also demonstrate that TGF- $\beta$ signaling is involved in periostin-related liver fibrosis. Our observations identify periostin as a potential diagnostic or therapeutic target for hepatic fibrosis.

\section{Materials and Methods}

\section{Experimental Models of Liver Fibrosis}

All experimental procedures involving animals were performed in accordance with animal protocols approved by the Institutional Animal Care and Use Committee of Xiamen University (Xiamen, China). Heterozygous

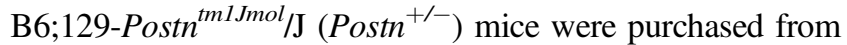
the Jackson Laboratory (Bar Harbor, ME). Wild-type and periostin-deficient mice were generated from crossing Postn $^{+/-}$mice with Postn ${ }^{+/-}$mice. Littermate controls were used in all experiments. All mice were housed in a specific pathogen-free environment. In the carbon tetrachloride-induced acute fibrosis model, male mice were injected i.p. with carbon tetrachloride (diluted 1:5 in sterile mineral oil) or vehicle (mineral oil) at a dose of $2.5 \mathrm{~mL} / \mathrm{kg}$ body weight twice per week for 2 weeks. In the carbon tetrachloride-induced chronic fibrosis model, male mice were injected i.p. with the same dose of carbon tetrachloride twice per week for 8 weeks. Mice were euthanized 72 hours after the final i.p. injection. To perform BDL, the common bile duct was ligated distally. We performed the sham operation similarly, except that the bile duct was not ligated. Mice were euthanized 1 or 3 weeks after BDL.

\section{Cell Culture}

The immortalized mouse macrophage cell line RAW264.7 was routinely cultured in Dulbecco's modified Eagle's medium (Gibco, Carlsbad, CA) with 10\% fetal bovine serum and $1 \%$ penicillin-streptomycin at $37^{\circ} \mathrm{C}$ and saturated with $5 \% \mathrm{CO}_{2}$ in a humidified atmosphere.

\section{IHC and Immunofluorescence}

Immunohistochemistry (IHC) and immunofluorescence staining were performed as described. ${ }^{27}$ The primary antibodies used included antibodies to periostin (AdipoGen, Liestal, Switzerland), fibronectin (BD Biosciences, Franklin Lakes, NJ), $\alpha$-smooth muscle actin ( $\alpha$-SMA; Santa Cruz Biotechnology, Santa Cruz, CA), collagen I, $\beta$-actin, and glyceraldehyde-3-phosphate dehydrogenase (Millipore, Billerica, MA).

\section{Immunoblotting Analysis}

Total proteins were extracted from liver tissues. Immunoblotting analysis was performed as described. ${ }^{27}$

\section{Real-Time PCR}

Total RNA was extracted from liver tissues or cells using TRIzol reagent, according to the manufacturer's instructions (Invitrogen, Carlsbad, CA). Reverse transcription was performed as previously described. ${ }^{27}$ The expression levels of the mRNAs were determined by real-time PCR using SYBR Premix Ex Taq (Takara, Liaoning, China) and the predesigned primers listed in Table 1.

\section{H\&E and Sirius Red Staining}

Before staining, paraffin-embedded sections (5 $\mu \mathrm{m}$ thick) were dewaxed and hydrated. For hematoxylin and eosin (H\&E) staining, nuclei were stained with hematoxylin, 
Table 1 List of All Primers Used for Real-Time PCR

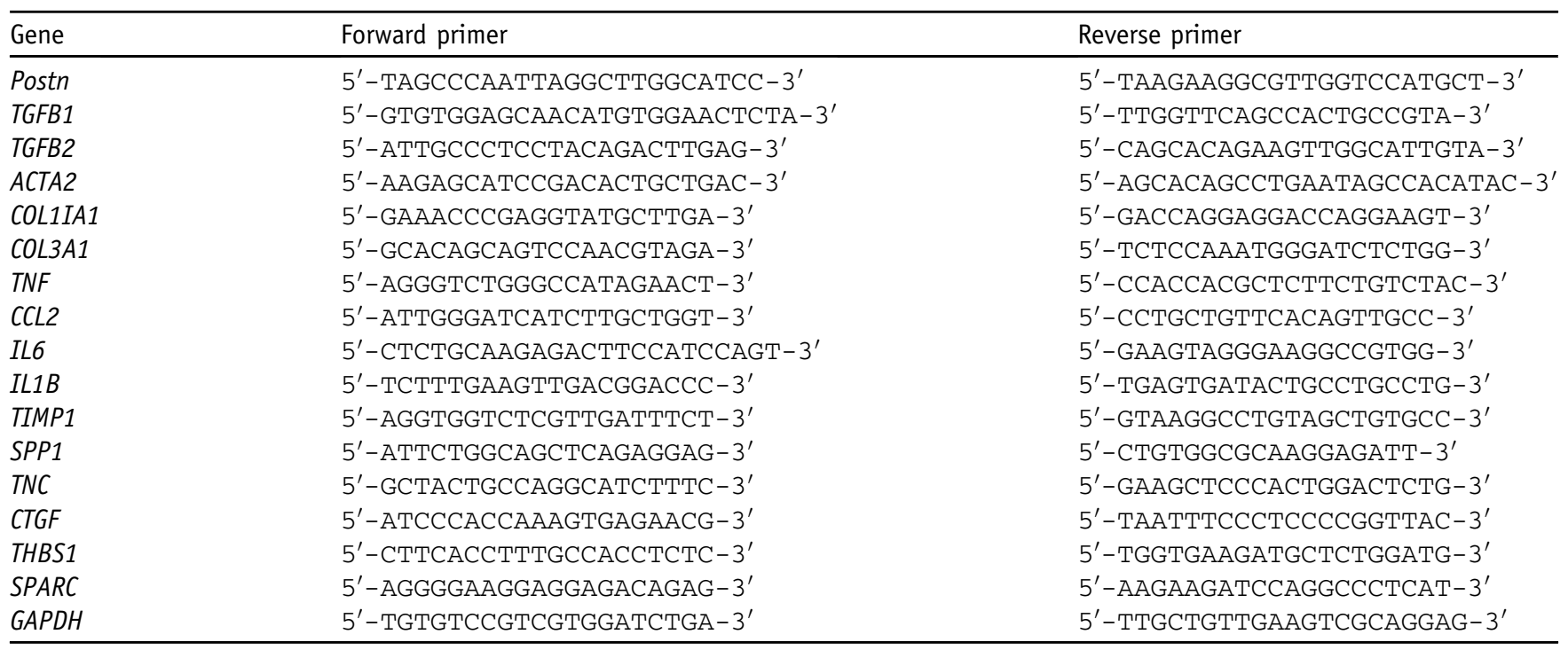

followed by staining with eosin. For Sirius red staining, the dewaxed sections were dyed with Picrosirius Red solution (0.1\% Direct Red 80 in saturated picric; Leagene, Beijing, China) for 1 hour, washed in acidified water, and dehydrated in three changes of $100 \%$ ethanol. The collagen deposition of Sirius red staining-positive area was quantified by Image Proplus version 6.0 (Media Cybernetics, Inc., Bethesda, MD).

\section{Determination of Hepatic Hydroxyproline Content}

The hepatic hydroxyproline content was determined in homogenized liver tissues. Briefly, liver samples were weighed and incubated in hydrochloric acid at $100^{\circ} \mathrm{C}$ for 5 hours. The acid hydrolysis was used to determine the content of hydroxyproline, according to the reagent kit's standard protocols (Nanjing Jiancheng Bioengineering Institute, Nanjing, China). The total hydroxyproline in collagen in whole liver specimens was quantified colorimetrically at 550 $\mathrm{nm}$ and expressed as per milligram of wet tissue weight.

\section{Serum ALT and AST Assays}

Ocular blood was collected and clotted at room temperature and centrifuged at $1000 \times g$ for 10 minutes, and the serum was collected. Alanine aminotransferase (ALT) and aspartate aminotransferase (AST) serum levels were determined by commercially available reagent kits (Biotech, Beijing, China), according to standard protocols.

\section{Isolation of Primary HSCs}

HSCs were isolated as described previously. ${ }^{28,29}$ Briefly, 2- to 3-month-old mice were anesthetized with phenobarbital sodium by i.p. injection and livers were perfused with Hanks' balanced salt solution (Sigma, St. Louis, MO), followed by Hanks' balanced salt solution containing collagenase II (Sigma) and Pronase (Roche, Basel, Switzerland). After perfusions, the liver was digested in collagenase solution for 10 minutes in a $37^{\circ} \mathrm{C}$ incubator, then minced with tweezers and pipetted repeatedly, filtered with a $70-\mu \mathrm{m}$ filter, and centrifuged at $50 \times g$ at $4^{\circ} \mathrm{C}$ for 2 minutes twice. The supernatant was centrifuged at $250 \times g$ for 10 minutes at $4^{\circ} \mathrm{C}$. HSCs were isolated by gradient centrifugation with Percoll (Sigma) and cultured in RPMI 1640 medium (Gibco) containing 10\% fetal bovine serum and penicillin/streptomycin. After 24 hours, the medium was changed. The purity of the cultured HSCs was $>90 \%$, as determined by fluorescence of lipid droplets containing vitamin A.

\section{Serum Periostin, TGF- $\beta 1$, and TGF- $\beta 2$ Assays}

All clinical serum samples were collected under informed consent of the patients, and study protocols were in accordance with the ethical guidelines and were approved by the Institutional Medical Ethics Committee of Xiamen University. Human serum samples were obtained from 28 normal donors, 32 acute hepatitis patients, and 20 chronic hepatitis patients. Serum levels of periostin, TGF- $\beta 1$, and TGF- $\beta 2$ were quantified with enzyme-linked immunosorbent assay kits (Shanghai Yanhui Biotechnology, Shanghai, China).

\section{Statistical Analysis}

The results are presented as the means \pm SEM for all experiments. Analysis was performed using one-way analysis of variance.

\section{Results}

Periostin Expression Is Up-Regulated in Mice with Acute or Chronic Liver Fibrosis

To determine whether periostin is involved in hepatic fibrosis, we used carbon tetrachloride to induce acute and 
A
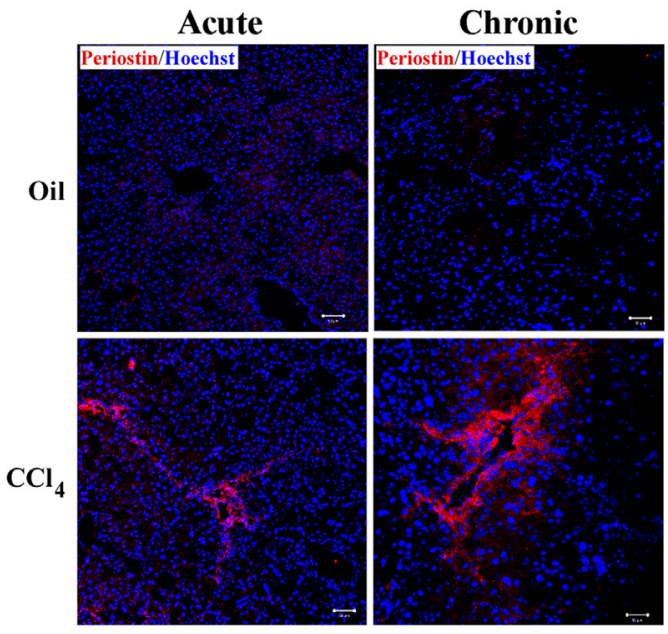

B

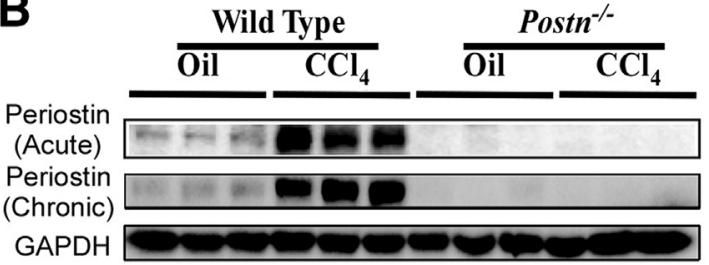

C
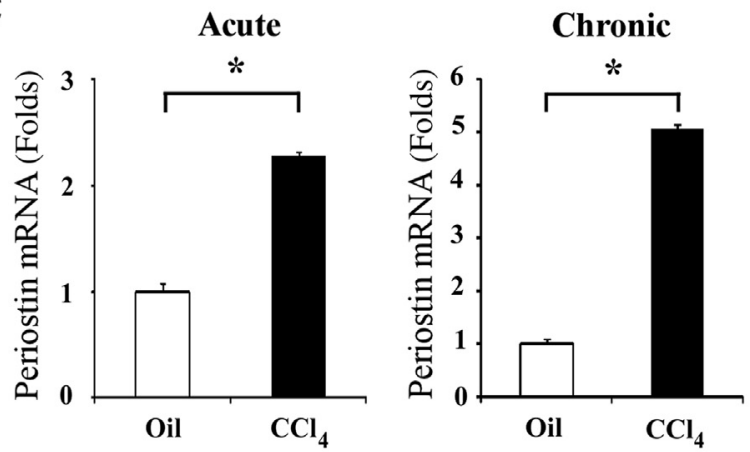

D
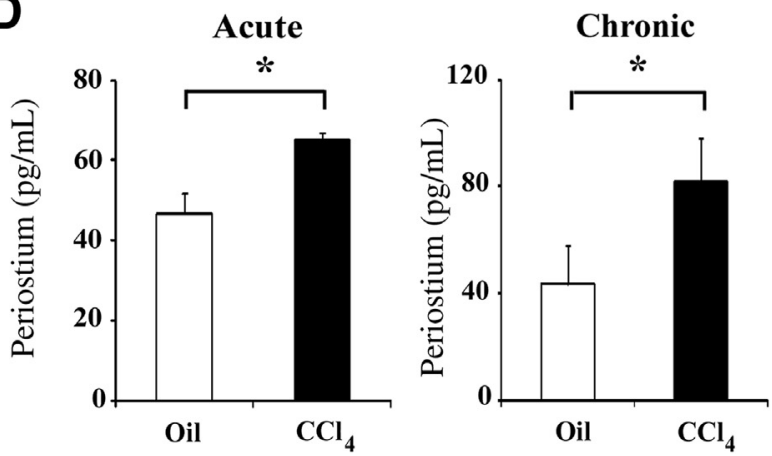

Figure 1 Periostin is up-regulated in mice with acute liver injury and chronic liver fibrosis. A: Immunofluorescence staining of periostin in carbon tetrachloride $\left(\mathrm{CCl}_{4}\right)$-induced acute and chronic fibrotic liver in mice. B: Western blot analysis of liver periostin levels in the carbon tetrachloride-induced acute and chronic fibrotic mice and the control groups administered mineral oil. C: RTqPCR analysis of liver periostin levels in the carbon tetrachloride-induced acute and chronic fibrotic mice and the control groups administered mineral oil. D: The serum periostin levels in the carbon tetrachloride-induced acute and chronic fibrotic mice and the control groups administered mineral oil as assessed by enzyme-linked immunosorbent assay. $n=3(\mathbf{C}$ and $\mathbf{D})$. ${ }^{*} P<0.05$. Scale bar $=$ $50 \mu \mathrm{m}($ A). GAPDH, glyceraldehyde-3-phosphate dehydrogenase. chronic liver fibrosis in mice. After 2 weeks of carbon tetrachloride exposure, the expression of hepatic periostin was significantly increased, as determined by immunofluorescence assay (Figure 1A). Consistent with the data for acute fibrosis, the expression of hepatic periostin was also elevated in mice treated with carbon tetrachloride for 8 weeks compared with mice treated with mineral oil (Figure 1A). We further performed Western blot analysis and real-time quantitative RT-PCR (RT-qPCR) to analyze the liver periostin expression in the carbon tetrachloride-induced acute and chronic fibrotic mice and the control groups administered mineral oil. Compared with the expression levels in the control groups, hepatic periostin protein and mRNA levels were significantly up-regulated in the liver tissues of mice with acute and chronic liver fibrosis induced by carbon tetrachloride treatment (Figure 1, B and C). Moreover, the serum levels of periostin were also significantly increased in the carbon tetrachloride-induced acute and chronic fibrotic mice compared with those in mineral oil-treated control mice (Figure 1D). It has been recognized that the mice with carbon tetrachloride-induced acute liver fibrosis will spontaneously recover from acute liver fibrosis after stopping carbon tetrachloride injection for 1 month $^{30}$; thus, we further examined the level of periostin in the recovered livers. We observed that the expression of periostin was abolished in the recovered livers after stopping the injection of carbon tetrachloride for 1 month (Supplemental Figure S1A).

To confirm the relationship between high levels of periostin and liver injury and fibrosis, we further used mice undergoing BDL or a sham operation for 1 or 3 weeks, which represent early fibrogenesis and septal fibrosis, respectively. By using immunofluorescence, Western blot analysis, and RT-qPCR assays, we found that the protein and mRNA levels of periostin were also elevated in BDL-induced liver injury and fibrosis (Supplemental Figure S2, A-C). These findings suggest that periostin may play a critical role in carbon tetrachloride - and BDL-induced liver fibrosis.

\section{Periostin Deficiency Ameliorates Liver Fibrosis in Mice}

Periostin expression was significantly up-regulated in carbon tetrachloride- and BDL-induced acute and chronic mouse liver fibrosis but decreased in the recovered livers. Thus, we speculated that the deletion of periostin may reduce liver fibrosis. We further used the Postn ${ }^{-1-}$ mouse model treated with oil or carbon tetrachloride to determine the role of periostin in liver fibrosis. Periostin-knockout and wild-type mice were i.p. administered mineral oil or carbon tetrachloride for 2 or 8 weeks, and were sacrificed at 72 hours after final i.p. injection. It is well known that activated HSCs express $\alpha$-SMA and secrete ECM proteins, such as collagen I, in response to liver injury. We therefore investigated the expression of $\alpha$-SMA and collagen I in acute and chronic fibrotic livers in periostin-deficient mice by immunofluorescence analysis. We found that $\alpha$-SMA and collagen 
I were expressed in a low level in the livers of wild-type and periostin-deficient mice treated with mineral oil for 2 or 8 weeks (Supplemental Figure S3); however, $\alpha$-SMA and collagen I levels were increased in wild-type mice after carbon tetrachloride treatment for 2 or 8 weeks, whereas these phenotypes were abolished in the livers of carbon tetrachloride-treated Postn ${ }^{-1-}$ mice (Figure 2). RT-qPCR analysis also revealed that carbon tetrachloride-treated Postn $^{-1-}$ mice exhibited a decreased liver mRNA level of $\alpha$-SMA and collagen I compared with wild-type counterparts with acute or chronic liver fibrosis (Figure 3, A and B). We also found that the mRNA level of collagen III $\alpha 1$ was robustly reduced in periostin-deficient mice compared with wild-type mice with chronic fibrosis; however, we could not find a significant difference in wild-type and knockout mice treated with carbon tetrachloride for 2 weeks (Figure 3C). We further determined the reduced fibrosis in Postn ${ }^{-1-}$ mice by Sirius red staining and hepatic hydroxyproline quantification. After 2 or 8 weeks of carbon tetrachloride treatment, the area of collagen deposition (Figure 3, D and E) and the hydroxyproline content (Supplemental Figure S4) in Posth $^{-1-}$ mice were markedly lower than in wild-type control mice. In addition, we detected the mRNA levels of several other fibrosis-related matricellular proteins, including OPN, CCN2, tenascin C, thrombospondin-1, and
SPARC, by RT-qPCR assay. We found that OPN mRNA was obviously decreased in periostin-deficient mice compared with wild-type mice after carbon tetrachloride treatment for 2 or 8 weeks. However, the mRNA expression of CCN2, tenascin C, thrombospondin-1, and SPARC was not altered significantly in periostin-deficient mice compared with wild-type mice after carbon tetrachloride treatment for 2 or 8 weeks (Supplemental Figure S5).

Furthermore, Postn ${ }^{-1-}$ mice showed a significant reduced serum level of ALT (Figure 4A) and AST (Figure 4B) compared with wild-type mice after 2 weeks of carbon tetrachloride administration. We also observed a decreased signal of F4/80 IHC staining in Postn ${ }^{-1-}$ mouse liver, indicating that macrophage infiltration and fibrosis development in Posth $^{-1-}$ mice was significantly attenuated compared with wild-type mice after 2 weeks of carbon tetrachloride administration (Figure 4C). In addition, the injured livers of wild-type mice had significantly increased mRNA expression for inflammatory and fibrotic genes, including those coding for chemokine ligand 2 , IL-6, IL- $1 \beta$, and tumor necrosis factor- $\alpha$, compared with expression in the mineral oil-treated controls. However, chemokine ligand 2, IL-6, IL- $1 \beta$, and tumor necrosis factor- $\alpha$ mRNA levels were significantly lower in $\mathrm{Posth}^{-1-}$ mice than in wild-type mice after carbon tetrachloride treatment for 2 weeks (Figure 4, D-G).

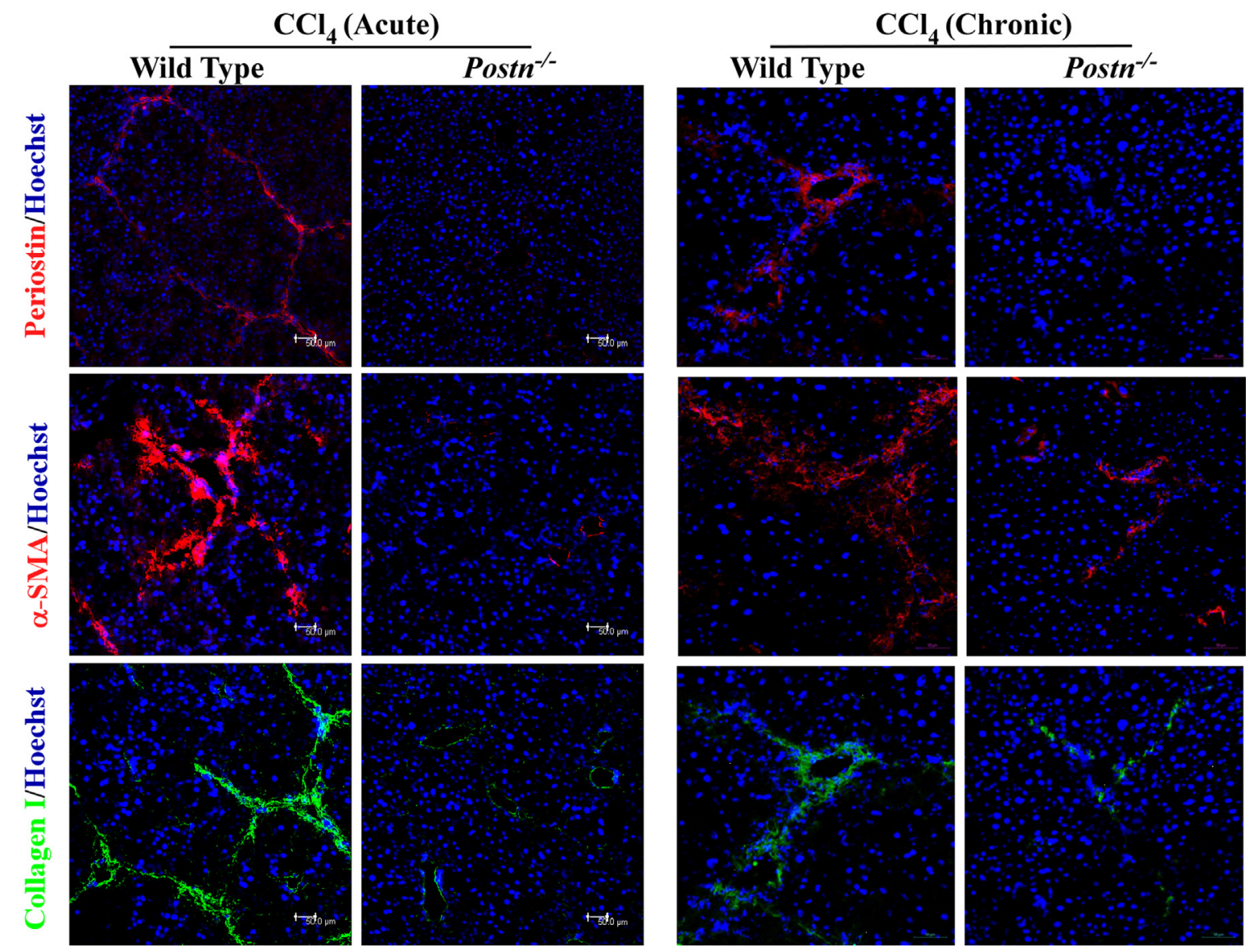

Figure 2 A deficiency in periostin reduces mouse liver fibrosis. Immunofluorescence analysis of periostin, $\alpha$ smooth muscle actin ( $\alpha$-SMA), and collagen I in wild-type and Postn ${ }^{-1-}$ mice after carbon tetrachloride $\left(\mathrm{CCl}_{4}\right)$ treatment for 2 or 8 weeks. Scale bar $=50 \mu \mathrm{m}$. 

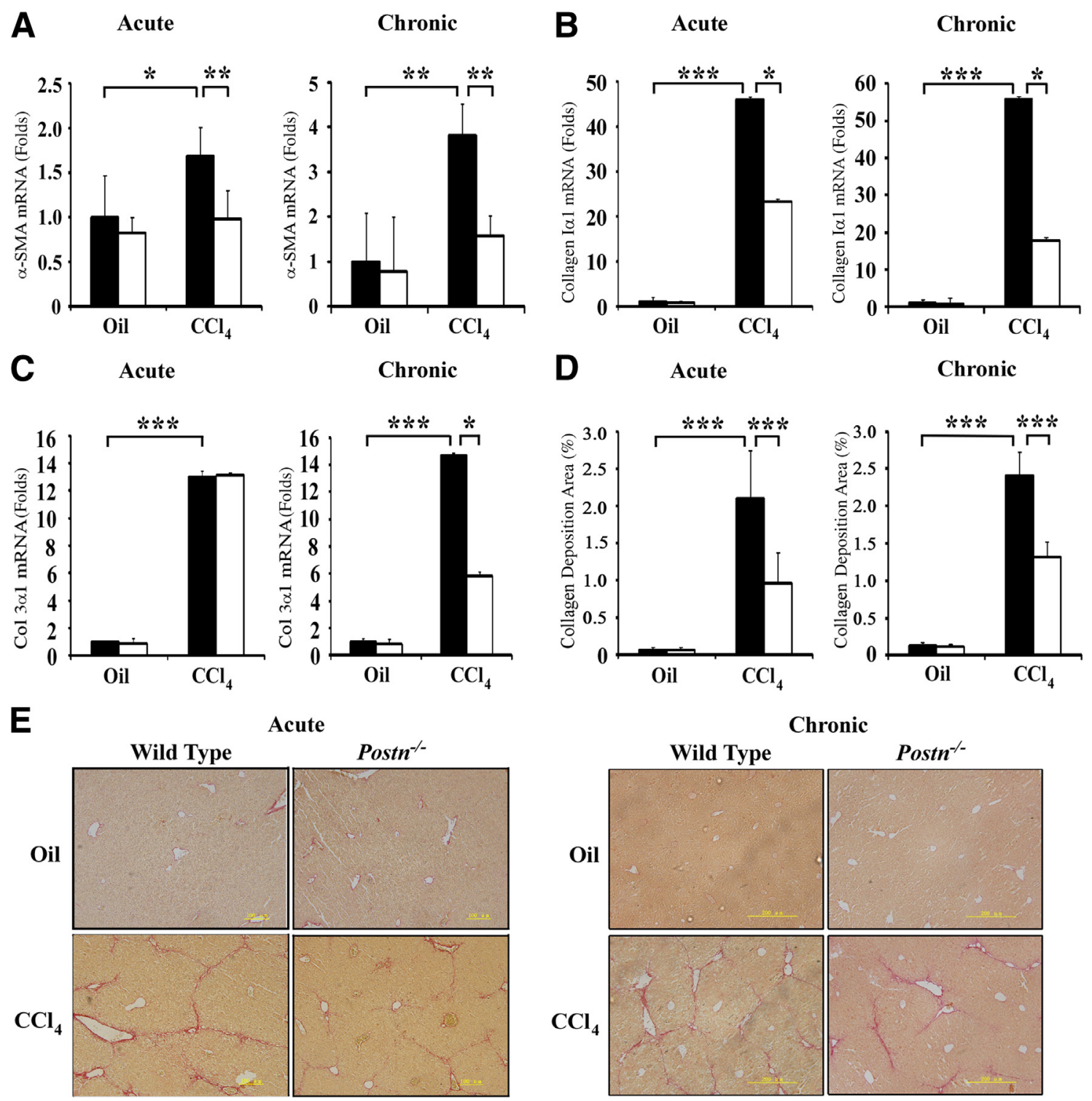

Figure 3 Periostin-deficient mice develop less liver injury and fibrosis than wild-type mice after carbon tetrachloride $\left(\mathrm{CCl}_{4}\right)$ treatment. RT-qPCR analysis of hepatic mRNA levels of $\alpha$ smooth muscle actin ( $\alpha$-SMA; A), collagen I $\alpha 1$ (B), and collagen III $\alpha 1$ (C) in wild-type (black bars) and Postn ${ }^{-/-}$(white bars) mice after carbon tetrachloride treatment for 2 or 8 weeks. Collagen deposition was analyzed by Sirius red staining (E) and quantification (D) in wild-type and Postn ${ }^{-/-}$mice after carbon tetrachloride treatment for 2 or 8 weeks. $n=3$ to $7(\mathbf{C}) ; n=4$ (D and E). ${ }^{*} P<0.05,{ }^{* *} P<0.01$, and ${ }^{* * *} P<0.001$. Scale bar $=$ $100 \mu \mathrm{m}(\mathbf{E})$.

Tissue inhibitor of metalloproteinase 1 plays a critical role in matrix remodeling, and its expression is significantly upregulated during fibrosis and cirrhosis. Postn ${ }^{-1-}$ mice exhibited a significantly lower tissue inhibitor of metalloproteinase 1 mRNA level than wild-type mice after carbon tetrachloride treatment for 2 weeks (Figure $4 \mathrm{H}$ ). Thus, these data suggest that a deficiency in periostin abrogates the development of liver fibrosis in mice.

\section{Periostin Can Be Secreted by the Activated HSCs}

It is widely accepted that liver fibrosis-related ECM proteins, such as fibronectin and collagen I, are mainly secreted by HSCs in response to liver injury. $\alpha$-SMA is another well-known hallmark of the activated HSCs. In the recovered mice, concomitant with the decreased expression of hepatic periostin, the hepatic levels of fibronectin, collagen I, and $\alpha$-SMA also declined after stopping carbon tetrachloride injection for 1 month (Supplemental Figure S1, B-D). Moreover, periostin colocalized with fibronectin, collagen I, and $\alpha$-SMA in fibrotic mouse livers after 2 weeks of carbon tetrachloride administration (Figure 5A). We also observed that periostin overlapped mostly with HSC-derived collagen I and $\alpha$-SMA in mouse chronic fibrotic liver tissues (Figure 5B). Thus, these data suggest that periostin may be produced by activated HSCs in the progression of carbon tetrachloride-induced liver fibrosis.

To further determine whether activated HSCs produce periostin, we isolated primary HSCs from mice with oil 


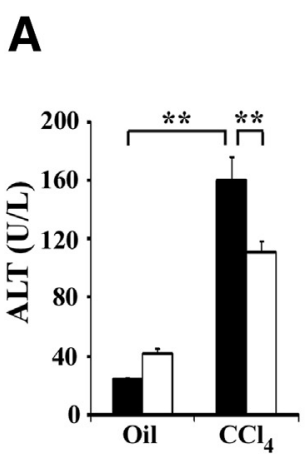

$\mathbf{E}$

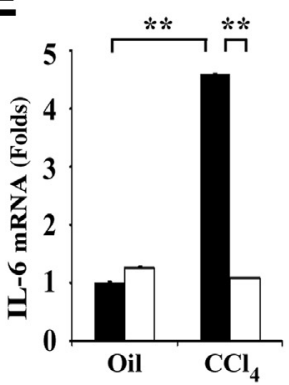

B

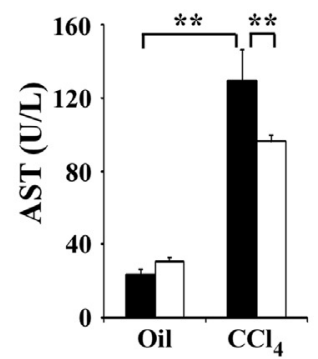

$\mathbf{F}$

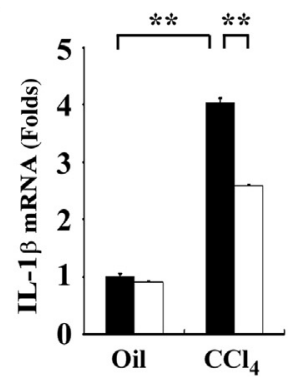

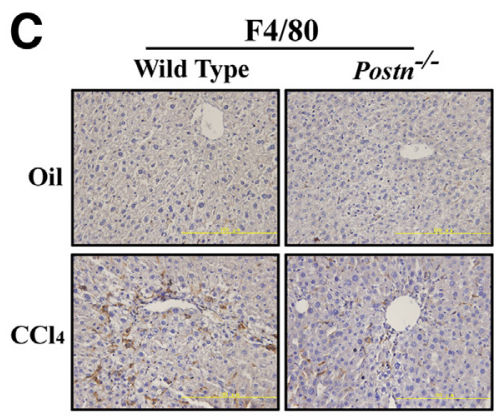

D

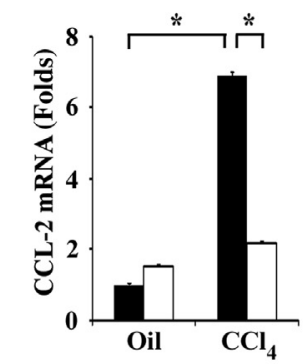

G

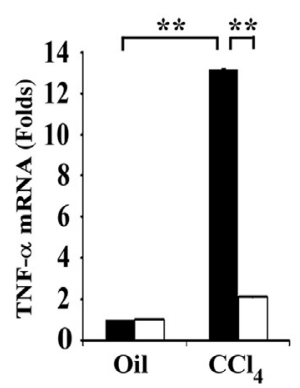

H

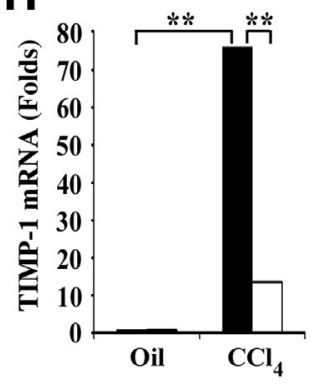

Figure 4 Liver injury and inflammation are decreased in the absence of periostin. Black bars indicate wild-type mice; white bars, Postn ${ }^{-1-}$. A and B: Postn $^{-1-}$ mice show significantly reduced serum levels of alanine aminotransferase (ALT; A) and aspartate aminotransferase (AST; B) compared with levels in wild-type mice after 2 weeks of carbon tetrachloride $\left(\mathrm{CCl}_{4}\right)$ administration. C: Immunohistochemical staining of F4/80-positive macrophages in wild-type and Postn $^{-1-}$ mice after carbon tetrachloride administration for 2 weeks. D-H: RT-qPCR analysis of hepatic mRNA levels of chemokine ligand (CCL) 2 (D), IL-6 (E), IL-1 $\beta$ (F), tumor necrosis factor- $\alpha$ (TNF- $\alpha ; \mathbf{G})$, and tissue inhibitor of metalloproteinase 1 (TIMP-1; H) in wild-type and Postn ${ }^{-/-}$mice after carbon tetrachloride treatment for 2 weeks. $n=3(\mathbf{A}, \mathbf{B}$, and $\mathbf{D}-\mathbf{H}) .{ }^{*} P<0.05,{ }^{*} P<0.01$. Scale bar $=100 \mu \mathrm{m}$ (C).

treatment, which were confirmed by phase-contrast microscopy and $\alpha$-SMA immunofluorescence staining (Supplemental Figure S6). TGF- $\beta 1$ is a critical profibrotic cytokine that activates HSCs during the development of hepatic fibrosis, so we assessed whether TGF- $\beta$ stimulates periostin expression in HSCs. Primary mouse HSCs did not express periostin; however, the expression of periostin was dramatically increased in primary HSCs after $10 \mathrm{ng} / \mathrm{mL}$ TGF- $\beta 1$ stimulation (Supplemental Figure S7). These results suggest that periostin can be secreted by the activated HSCs.

\section{TGF- $\beta$ Is Involved in Periostin-Related Mouse Liver Fibrosis}

Because TGF- $\beta 1$ significantly induces the expression of periostin in primary mouse HSCs, we further determined whether periostin could regulate the level of TGF- $\beta$ in liver fibrosis. We found that the mRNA level of TGF- $\beta 1$ and TGF- $\beta 2$ was significantly increased in the liver tissues of mice with acute or chronic liver fibrosis compared with the mineral oil-treated control groups. However, periostin-deficient mice showed a significantly lower liver level of TGF- $\beta 1$ and TGF- $\beta 2$ mRNA than the wild-type mice after carbon tetrachloride treatment for 2 (Figure $6 \mathrm{~A}$ ) or 8 (Figure $6 \mathrm{~B}$ ) weeks. The serum levels of TGF- $\beta 1$ and TGF- $\beta 2$ in periostin-deficient mice were also significantly lower than those in the wild-type mice after carbon tetrachloride treatment for 2 weeks (Figure 6C). It has been reported that liverresident and bone marrow-derived macrophages are the major source of TGF- $\beta$ in the fibrotic liver. To further evaluate whether periostin could induce TGF- $\beta$ in macrophages in liver fibrosis, we detected the mRNA levels of TGF- $\beta 1$ and TGF- $\beta 2$ in the mouse macrophage cell line RAW264.7 after stimulation with human recombinant periostin protein. We found that recombinant periostin treatment strongly up-regulated the mRNA levels of TGF- $\beta 1$ and TGF- $\beta 2$ in RAW264.7 cells (Figure 6D). Therefore, these results indicate that TGF- $\beta$ is involved in periostin-related mouse liver fibrosis development.

High Levels of Periostin Are Correlated with TGF- $\beta 1$ and TGF- $\beta 2$ Expression in Serum from Patients with Hepatitis

To further define the role of periostin in the development of human hepatitis and to determine the correlation between periostin and TGF- $\beta$, we detected the levels of periostin and TGF- $\beta$ in the serum of patients with acute or chronic hepatitis. A high level of periostin was found in serum from patients with acute or chronic hepatitis compared with the serum from healthy controls without hepatitis (Figure 7A). Interestingly, the serum levels of TGF- $\beta 1$ and TGF- $\beta 2$ in acute and chronic hepatitis significantly increased compared with the serum levels in healthy controls without hepatitis. Moreover, there was a positive correlation between the levels of serum periostin and TGF- $\beta 1$ in patients with acute or chronic hepatitis (Figure 7B). Another correlation was found between the levels of serum periostin and TGF- $\beta 2$ in 

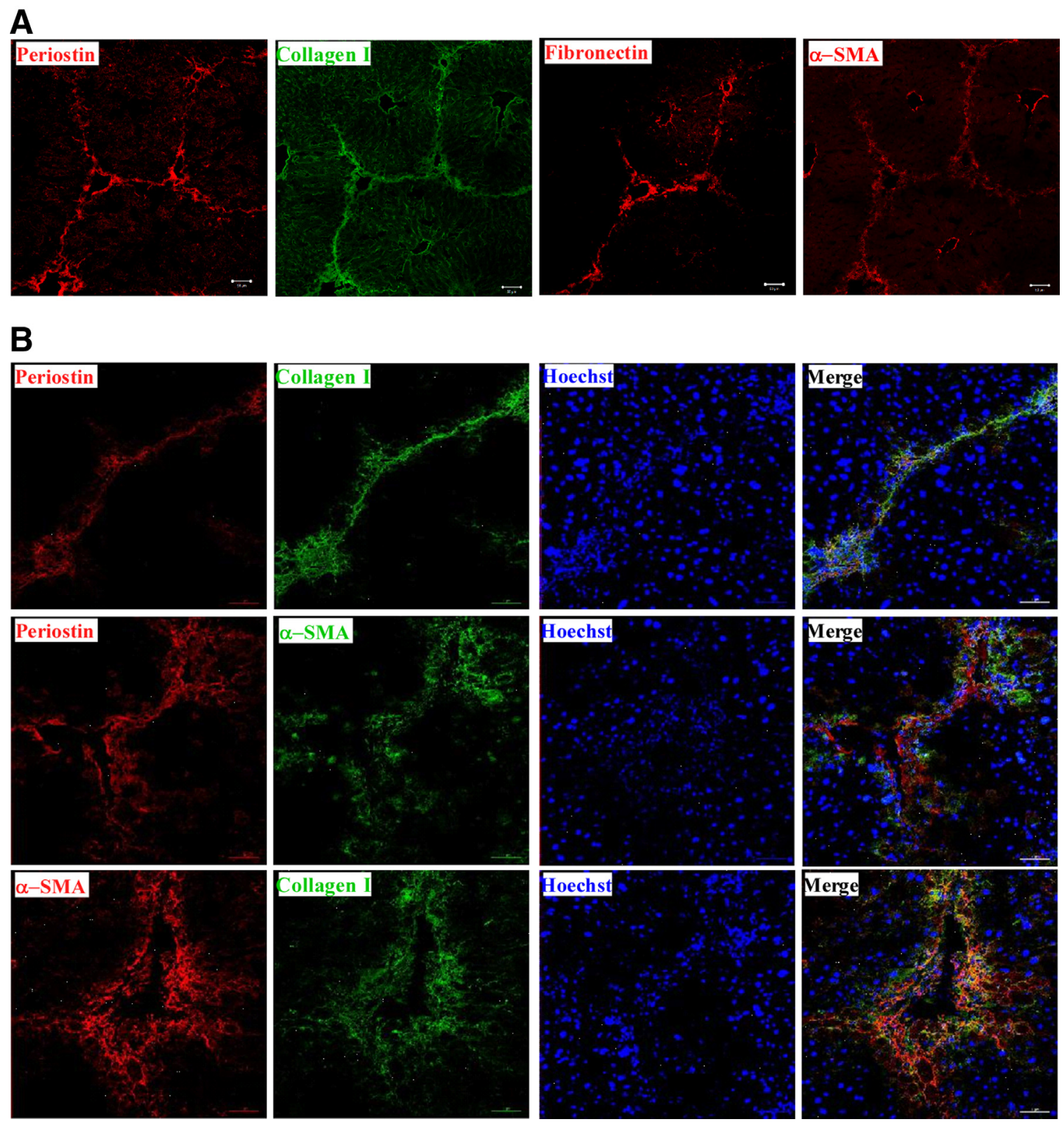

Figure 5 Periostin colocalizes with collagen I, fibronectin, and $\alpha$ smooth muscle actin ( $\alpha$-SMA) in fibrotic mouse liver tissues. A: Immunofluorescence staining of periostin, collagen I, fibronectin, and $\alpha$-SMA in acute fibrotic liver sections from carbon tetrachloride $\left(\mathrm{CCl}_{4}\right)$-treated wild-type mice. B: Immunofluorescence staining of periostin, collagen I, and $\alpha$-SMA in chronic fibrotic liver sections from carbon tetrachloride-treated wild-type mice. Scale bar $=50 \mu \mathrm{m}(\mathbf{A}$ and $\mathbf{B})$.

patients with acute or chronic hepatitis (Figure 7C). In summary, these observations indicate that periostin expression is associated with TGF- $\beta 1$ and TGF- $\beta 2$ levels in human hepatic inflammation and fibrosis.

\section{Discussion}

Fibrosis is the formation of excess fibrous connective tissues, which can be defined as an out-of-control wound-healing process. $^{31}$ Hepatic fibrosis occurs as a wound-healing response after acute or chronic liver inflammation that involves the progressive excess production and deposition of ECM components. During the inflammatory cascade in liver injury, resident macrophages and HSCs, together with recruited infiltrating leukocytes and bone marrow-derived cells, contribute to remodeling the ECM composition and tissue architecture. Fibrosis is characterized by the aberrant deposition of ECM proteins, such as collagens, fibronectins, and laminins. Collagen fibrillar formation is a critical step in fibrogenesis. As a non-structural ECM protein, periostin can regulate fibrillogenesis by changing the biophysical and biochemical properties of the ECM. ${ }^{10,12}$ Periostin binds to collagen I to promote fibrillogenesis 
A

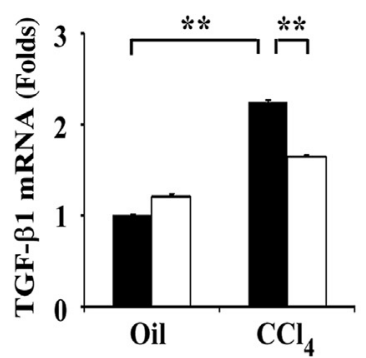

B

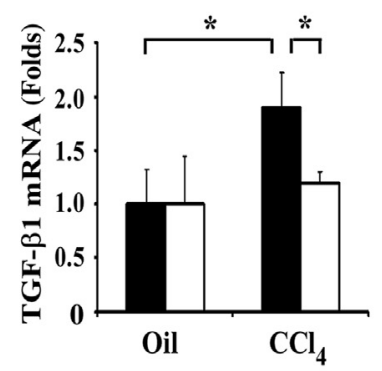

C
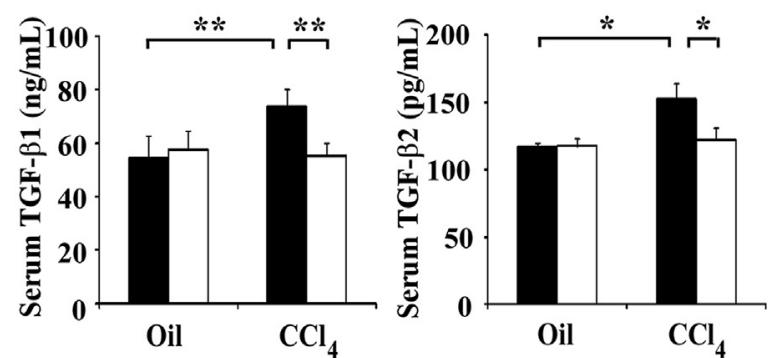

D
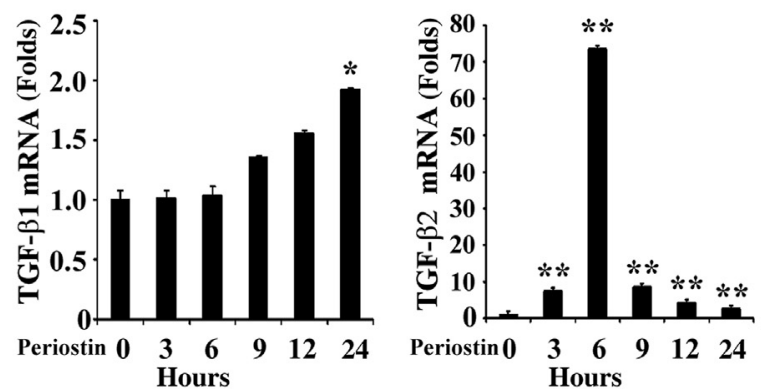

Figure 6 Periostin-deficient mice (black bars, A-C) show a significantly lower level of liver and serum transforming growth factor (TGF)$\beta 1$ and TGF- $\beta 2$ than the wild-type mice (white bars, $\mathbf{A}-\mathbf{C}$ ) after carbon tetrachloride $\left(\mathrm{CCl}_{4}\right)$ treatment for 2 weeks. A: RT-qPCR analysis of TGF$\beta 1$ and TGF- $\beta 2$ mRNA levels in the liver of wild-type and periostindeficient mice after carbon tetrachloride treatment for 2 weeks. B: RT-qPCR analysis of TGF- $\beta 1$ and TGF- $\beta 2$ mRNA levels in the liver of wildtype and periostin-deficient mice after carbon tetrachloride treatment for 8 weeks. C: Enzyme-linked immunosorbent assay analysis of the serum levels of TGF- $\beta 1$ and TGF- $\beta 2$ in the wild-type and periostindeficient mice after carbon tetrachloride treatment for 2 weeks. D: Periostin promotes the expression of TGF- $\beta 1$ and TGF- $\beta 2$ in the mouse macrophage cell line RAW264.7. RT-qPCR analysis of the mRNA levels of TGF- $\beta 1$ and TGF- $\beta 2$ in RAW264.7 cells after stimulation with $150 \mathrm{ng} / \mathrm{mL}$ human recombinant periostin protein for the indicated times. $n=3$ $(\mathbf{A}-\mathbf{C}) .{ }^{*} P<0.05,{ }^{*} P<0.01$. and also enhances collagen formation in the chronic phase of allergic skin inflammation. ${ }^{10,13}$ Periostin-null mice exhibit aberrant collagen I fibrillogenesis. ${ }^{9}$ Current data reveal that periostin can directly interact with collagen I, fibronectin, and Notch1 via its EMI domain and interact with tenascin $\mathrm{C}$ and bone morphogenetic protein 1 via its FAS I domains. Periostin can recruit bone morphogenetic protein 1 onto the fibronectin matrix to promote lysyl oxidase activity for collagen cross-linkage. ${ }^{12,32,33}$ These studies highlight the importance of periostin in ECM homeostasis and remodeling. ${ }^{6,15}$ Herein, our data showed that periostin not only increased concomitantly with upregulated collagen I and fibronectin in mouse hepatic fibrosis and decreased together with down-regulated collagen I and fibronectin in the recovered livers but also colocalized with collagen I and fibronectin in hepatic fibrosis. Therefore, overexpressed periostin, collagen I, and fibronectin in acute and chronic liver inflammation accelerate fibrillogenesis, which ultimately leads to hepatic fibrosis.

Liver injury triggers inflammation and excessive production of ECM and is usually accompanied by tissue repair, but continuous liver injury may lead to liver fibrosis. Current evidence demonstrates that periostin undergoes a transient up-regulation in response to stresses or insults in the targeted tissue and the tissue may fail to repair appropriately if periostin is not adequate; however, sustained overexpression of periostin makes the tissue repair out of control. ${ }^{15}$ We detected the serum levels of ALT and AST in wild-type and periostindeficient mice 48 hours after one injection of carbon tetrachloride and found that periostin-deficient mice exhibited a significantly increased serum level of ALT and AST compared with wild-type mice (Supplemental Figure S8). Meanwhile, our work showed that periostin-deficient mice had a reduction in serum ALT and AST activity compared with wild-type mice after 2 weeks of treatment with carbon tetrachloride. These data suggest that periostin may protect the liver from drug injury during early period and that periostin deficiency will ameliorate liver fibrosis during advanced development. Therefore, a timely expression and adequate periostin will facilitate tissue repair in response to liver injury insult in the early period, but a continuous high level of periostin or too much periostin will contribute to acute and chronic fibrosis in liver tissues.

TGF- $\beta$ is a major factor accelerating the development of hepatic fibrosis by promoting the transdifferentiation and migration of HSCs. Activated HSCs can promote hepatic fibrosis progression through autocrine and paracrine loops of TGF- $\beta$-stimulated collagen production. ${ }^{34}$ Periostin is a TGF- $\beta$-responsive gene product, which is increased in rat carotid arteries after injury and stimulation with TGF- $\beta{ }^{35}$ Periostin also can regulate TGF- $\beta$ signaling in various diseases. Periostin-null mice exhibit markedly decreased phosphorylated Smad2 and Smad3 in endocardial cushions/leaflets at E14 compared with wild-type controls. ${ }^{36}$ IL-13-induced periostin in asthma up-regulates the expression of TGF- $\beta$ and 

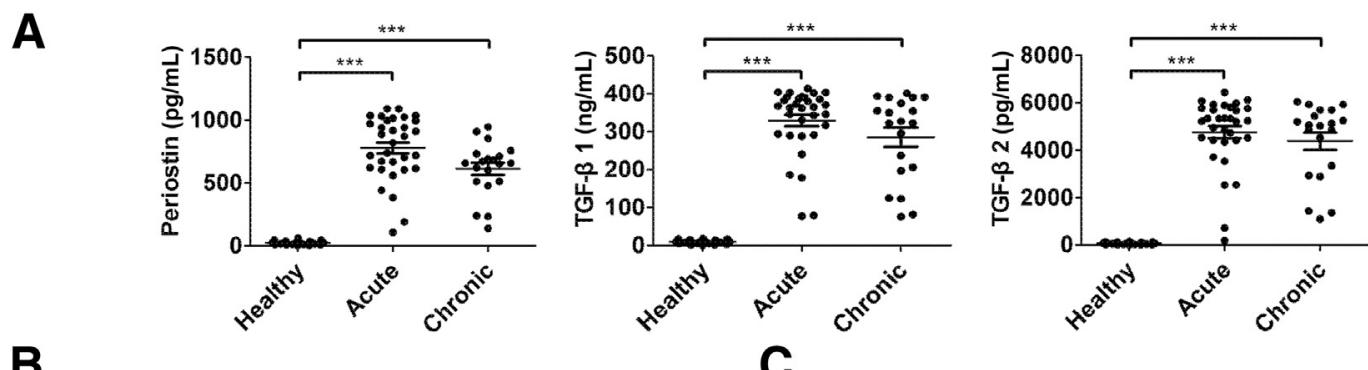

B
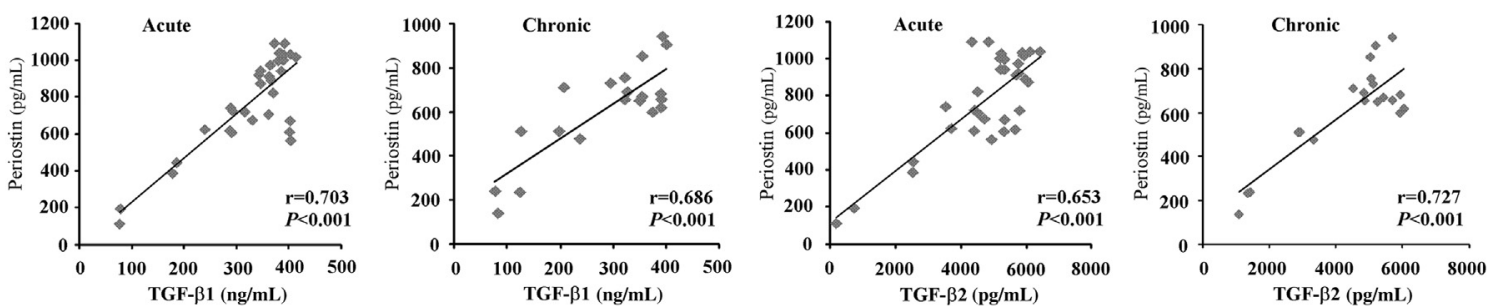

Figure 7 Periostin expression is associated with transforming growth factor (TGF)- $\beta 1$ and TGF- $\beta 2$ levels in human hepatic fibrosis. A: Enzyme-linked immunosorbent assay analysis of serum periostin, TGF- $\beta 1$, and TGF- $\beta 2$ levels in patients with acute or chronic hepatitis and healthy controls without hepatitis. B: Correlation analysis of the levels of serum periostin and TGF- $\beta 1$ in patients with acute or chronic hepatitis. C: Correlation analysis of the levels of serum periostin and TGF- $\beta 2$ in patients with acute or chronic hepatitis. ${ }^{* *} P<0.001$.

collagen I. Periostin secreted by epithelial cells also cross-links with collagen I to alter the biomechanical properties of the airway. ${ }^{37}$ Periostin deletion reduces muscular dystrophy and fibrosis by regulating TGF- $\beta$ signaling. ${ }^{38}$ Periostin accelerates pathological fibrosis in both bleomycin-induced murine skin sclerosis and human scleroderma by promoting myofibroblast differentiation and collagen synthesis via the regulation of TGF$\beta 1$ activity. ${ }^{39}$ Interestingly, infiltrating breast cancer stem cells can educate lung fibroblasts by secreting factors such as TGF- $\beta$, which induces periostin expression in fibroblasts to generate a metastatic niche to support lung metastasis. ${ }^{21}$ Periostin and TGF- $\beta$ are highly expressed in sprouting neovasculature niches to activate dormant cancer cells to undergo micrometastatic outgrowth. ${ }^{40}$ These observations suggest that both periostin and TGF- $\beta$ actively contribute to remodeling local tissue microenvironment in tissue injury, inflammation, fibrosis, and tumor metastasis. During liver fibrosis, quiescent HSCs can be activated into collagen I- and $\alpha$-SMA-positive myofibroblasts after TGF- $\beta$ stimulation. Herein, lower mRNA and protein levels of TGF- $\beta 1$ and TGF- $\beta 2$ were found in the livers of carbon tetrachloride-treated periostin-deficient mice compared with their wild-type counterparts. Moreover, high levels of periostin were correlated with TGF- $\beta 1$ and TGF- $\beta 2$ expression in serum from patients with acute or chronic hepatitis. Because TGF- $\beta$ is a major profibrogenic cytokine and a central regulator of liver fibrosis, the capacity of periostin to influence TGF- $\beta$ pathways suggests that HSC-derived periostin might function, at least in part, to regulate TGF- $\beta$ activity in liver fibrosis. Conversely, TGF- $\beta$ can induce a high level of periostin in the isolated primary HSCs, indicating that there may be a reciprocal regulatory mechanism between TGF- $\beta$ and periostin in liver fibrosis. Taken together, our data demonstrate that persistent liver injury and inflammatory stimuli result in hepatic resident and recruited macrophages to secrete profibrogenic cytokines, such as TGF- $\beta$; this cytokine activates HSCs to produce excessive ECM proteins, such as collagen I, fibronectin, and periostin. Among these ECM proteins, periostin, in turn, might induce macrophages to produce TGF- $\beta$, thereby generating a vicious circle in the development of liver fibrosis. Furthermore, periostin, as a remodeling matricellular protein, might directly bind with collagen I and fibronectin to promote fibrillogenesis, which partly accounts for acute and chronic liver fibrosis. In addition, the activated HSCderived periostin also might serve as one of chemotactic factors to recruit macrophages into the damaging liver. Further studies are required to address these issues and the underlying molecular mechanisms.

It is of interest that several matricellular proteins, such as OPN ${ }^{41-43}$ tenascin $\mathrm{C},{ }^{44}$ and SPARC, ${ }^{45-47}$ are also involved in hepatic fibrosis. This study, thus, reinforces the notion that there may be functional similarities between matricellular proteins in remodeling the tissue microenvironment in hepatic fibrosis and other inflammatory diseases. An excessive or uncontrolled function of these matricellular proteins may contribute to aberrant remodeling and homeostasis of tissue microenvironment in various inflammatory diseases. In addition, $\mathrm{OPN},{ }^{48}$ tenascin $\mathrm{C},{ }^{49}$ periostin, ${ }^{21,50}$ and other matricellular proteins have been reported to promote tumor metastasis by modulating metastatic niches. These matricellular proteins are often associated with the need for ECM remodeling during embryonic development and are also highly expressed at sites of injury or inflammation or tumor sites within an adult organism. Therefore, a systemic evaluation of how these matricellular proteins regulate tissue inflammatory and tumor microenvironment will help in the development of therapeutic strategies to treat hepatic fibrosis and other inflammatory diseases. 


\section{Acknowledgments}

G.O., Y.H., and W.L. conceived and designed the experiments; Y.H., W.L., H.X., A.M., and T.W. performed the experiments; G.O., Y.H., and W.L. analyzed the data; Q.L., Z.H., F.L., and Q.L. contributed reagents/materials/analysis tools; and G.O. and Y.H. wrote the manuscript.

\section{Supplemental Data}

Supplemental material for this article can be found at http://dx.doi.org/10.1016/j.ajpath.2014.11.002.

\section{References}

1. Bataller R, Brenner DA: Liver fibrosis. J Clin Invest 2005, 115: 209-218

2. Friedman SL: Evolving challenges in hepatic fibrosis. Nat Rev Gastroenterol Hepatol 2010, 7:425-436

3. Zhang DY, Friedman SL: Fibrosis-dependent mechanisms of hepatocarcinogenesis. Hepatology 2012, 56:769-775

4. Bornstein P: Diversity of function is inherent in matricellular proteins: an appraisal of thrombospondin 1. J Cell Biol 1995, 130:503-506

5. Ruan K, Bao S, Ouyang G: The multifaceted role of periostin in tumorigenesis. Cell Mol Life Sci 2009, 66:2219-2230

6. Wu T, Ouyang G: Matricellular proteins: multifaceted extracellular regulators in tumor dormancy. Protein Cell 2014, 5:249-252

7. Takeshita S, Kikuno R, Tezuka K, Amann E: Osteoblast-specific factor 2: cloning of a putative bone adhesion protein with homology with the insect protein fasciclin I. Biochem J 1993, 294:271-278

8. Horiuchi K. Amizuka N, Takeshita S, Katsuura M, Ozawa H, Toyama Y, Bonewald LF, Kudo A: Identification and characterization of a novel protein, periostin, with restricted expression to periosteum and periodontal ligament and increased expression by transforming growth factor beta. J Bone Miner Res 1999, 14: $1239-1249$

9. Rios H, Koushik SV, Wang H, Wang J, Zhou HM, Lindsley A, Rogers R, Chen Z, Maeda M, Kruzynska-Frejtag A, Feng JQ, Conway SJ: Periostin null mice exhibit dwarfism, incisor enamel defects, and an early-onset periodontal disease-like phenotype. Mol Cell Biol 2005, 25:11131-11144

10. Norris RA, Damon B, Mironov V, Kasyanov V, Ramamurthi A, Moreno-Rodriguez R, Trusk T, Potts JD, Goodwin RL, Davis J, Hoffman S, Wen X, Sugi Y, Kern CB, Mjaatvedt CH, Turner DK, Oka T, Conway SJ, Molkentin JD, Forgacs G, Markwald RR: Periostin regulates collagen fibrillogenesis and the biomechanical properties of connective tissues. J Cell Biochem 2007, 101:695-711

11. Bonnet N, Standley KN, Bianchi EN, Stadelmann V, Foti M, Conway SJ, Ferrari SL: The matricellular protein periostin is required for sost inhibition and the anabolic response to mechanical loading and physical activity. J Biol Chem 2009, 284:35939-35950

12. Kudo A: Periostin in fibrillogenesis for tissue regeneration: periostin actions inside and outside the cell. Cell Mol Life Sci 2011, 68 3201-3207

13. Masuoka M, Shiraishi H, Ohta S, Suzuki S, Arima K, Aoki S, Toda S, Inagaki N, Kurihara Y, Hayashida S, Takeuchi S, Koike K, Ono J, Noshiro H, Furue M, Conway SJ, Narisawa Y, Izuhara K: Periostin promotes chronic allergic inflammation in response to Th2 cytokines. J Clin Invest 2012, 122:2590-2600

14. Sen K, Lindenmeyer MT, Gaspert A, Eichinger F, Neusser MA Kretzler M, Segerer S, Cohen CD: Periostin is induced in glomerular injury and expressed de novo in interstitial renal fibrosis. Am J Pathol 2011, 179:1756-1767
15. Conway SJ, Izuhara K, Kudo Y, Litvin J, Markwald R, Ouyang G, Arron JR, Holweg CT, Kudo A: The role of periostin in tissue remodelling across health and disease. Cell Mol Life Sci 2014, 71:1279-1288

16. Hakuno D, Kimura N, Yoshioka M, Mukai M, Kimura T, Okada Y, Yozu R, Shukunami C, Hiraki Y, Kudo A, Ogawa S, Fukuda K: Periostin advances atherosclerotic and rheumatic cardiac valve degeneration by inducing angiogenesis and MMP production in humans and rodents. J Clin Invest 2010, 120:2292-2306

17. Kuhn B, del Monte F, Hajjar RJ, Chang YS, Lebeche D, Arab S, Keating MT: Periostin induces proliferation of differentiated cardiomyocytes and promotes cardiac repair. Nat Med 2007, 13:962-969

18. Dobaczewski M, Gonzalez-Quesada C, Frangogiannis NG: The extracellular matrix as a modulator of the inflammatory and reparative response following myocardial infarction. J Mol Cell Cardiol 2010, 48: 504-511

19. Takayama G, Arima K, Kanaji T, Toda S, Tanaka H, Shoji S, McKenzie AN, Nagai H, Hotokebuchi T, Izuhara K: Periostin: a novel component of subepithelial fibrosis of bronchial asthma downstream of IL-4 and IL-13 signals. J Allergy Clin Immunol 2006, 118:98-104

20. Bao S, Ouyang G, Bai X, Huang Z, Ma C, Liu M, Shao R, Anderson RM, Rich JN, Wang XF: Periostin potently promotes metastatic growth of colon cancer by augmenting cell survival via the Akt/PKB pathway. Cancer Cell 2004, 5:329-339

21. Malanchi I, Santamaria-Martinez A, Susanto E, Peng H, Lehr HA, Delaloye JF, Huelsken J: Interactions between cancer stem cells and their niche govern metastatic colonization. Nature 2012, 481:85-89

22. Wang X, Liu J, Wang Z, Huang Y, Liu W, Zhu X, Cai Y, Fang X, Lin S, Yuan L, Ouyang G: Periostin contributes to the acquisition of multipotent stem cell-like properties in human mammary epithelial cells and breast cancer cells. PLoS One 2013, 8:e72962

23. Kikuchi Y, Kunita A, Iwata C, Komura D, Nishiyama T, Shimazu K, Takeshita K, Shibahara J, Kii I, Morishita Y, Yashiro M, Hirakawa K, Miyazono K, Kudo A, Fukayama M, Kashima TG: The niche component periostin is produced by cancer-associated fibroblasts, supporting growth of gastric cancer through ERK activation. Am J Pathol 2014, 184:859-870

24. Liu AY, Zheng H, Ouyang G: Periostin, a multifunctional matricellular protein in inflammatory and tumor microenvironments. Matrix Biol 2014, 37:150-156

25. Lu Y, Liu X, Jiao Y, Xiong X, Wang E, Wang X, Zhang Z, Zhang H, Pan L, Guan Y, Cai D, Ning G, Li X: Periostin promotes liver steatosis and hypertriglyceridemia through downregulation of PPAR $\alpha$. J Clin Invest 2014, 124:3501-3513

26. Wu T, Wu S, Ouyang G: Periostin: a new extracellular regulator of obesity-induced hepatosteatosis. Cell Metab 2014, 20:562-564

27. Fang X, Cai Y, Liu J, Wang Z, Wu Q, Zhang Z, Yang CJ, Yuan L, Ouyang G: Twist2 contributes to breast cancer progression by promoting an epithelial-mesenchymal transition and cancer stem-like cell self-renewal. Oncogene 2011, 30:4707-4720

28. Copple BL, Bai S, Burgoon LD, Moon JO: Hypoxia-inducible factor$1 \alpha$ regulates the expression of genes in hypoxic hepatic stellate cells important for collagen deposition and angiogenesis. Liver Int 2011, $31: 230-244$

29. Maschmeyer P, Flach M, Winau F: Seven steps to stellate cells. J Vis Exp 2011, (51). pii:2710

30. Yoshiji H, Kuriyama S, Yoshii J, Ikenaka Y, Noguchi R, Nakatani T, Tsujinoue H, Yanase K, Namisaki T, Imazu H, Fukui H: Tissue inhibitor of metalloproteinases-1 attenuates spontaneous liver fibrosis resolution in the transgenic mouse. Hepatology 2002, 36:850-860

31. Wynn TA: Cellular and molecular mechanisms of fibrosis. J Pathol 2008, 214:199-210

32. Maruhashi T, Kii I, Saito M, Kudo A: Interaction between periostin and BMP-1 promotes proteolytic activation of lysyl oxidase. J Biol Chem 2010, 285:13294-13303

33. Kii I, Nishiyama T, Li M, Matsumoto K, Saito M, Amizuka N, Kudo A: Incorporation of tenascin-C into the extracellular matrix by 
periostin underlies an extracellular meshwork architecture. J Biol Chem 2009, 285:2028-2039

34. Inagaki Y, Okazaki I: Emerging insights into transforming growth factor beta Smad signal in hepatic fibrogenesis. Gut 2007, 56:284-292

35. Li G, Oparil S, Sanders JM, Zhang L, Dai M, Chen LB, Conway SJ, McNamara CA, Sarembock IJ: Phosphatidylinositol-3-kinase signaling mediates vascular smooth muscle cell expression of periostin in vivo and in vitro. Atherosclerosis 2006, 188:292-300

36. Snider P, Hinton RB, Moreno-Rodriguez RA, Wang J, Rogers R, Lindsley A, Li F, Ingram DA, Menick D, Field L, Firulli AB, Molkentin JD, Markwald R, Conway SJ: Periostin is required for maturation and extracellular matrix stabilization of noncardiomyocyte lineages of the heart. Circ Res 2008, 102:752-760

37. Sidhu SS, Yuan S, Innes AL, Kerr S, Woodruff PG, Hou L, Muller SJ, Fahy JV: Roles of epithelial cell-derived periostin in TGFbeta activation, collagen production, and collagen gel elasticity in asthma. Proc Natl Acad Sci USA 2010, 107:14170-14175

38. Lorts A, Schwanekamp JA, Baudino TA, McNally EM, Molkentin JD: Deletion of periostin reduces muscular dystrophy and fibrosis in mice by modulating the transforming growth factor- $\beta$ pathway. Proc Natl Acad Sci USA 2012, 109:10978-10983

39. Yang L, Serada S, Fujimoto M, Terao M, Kotobuki Y, Kitaba S, Matsui S, Kudo A, Naka T, Murota H, Katayama I: Periostin facilitates skin sclerosis via PI3K/Akt dependent mechanism in a mouse model of scleroderma. PLoS One 2012, 7:e41994

40. Ghajar CM, Peinado H, Mori H, Matei IR, Evason KJ, Brazier H, Almeida D, Koller A, Hajjar KA, Stainier DY, Chen EI, Lyden D, Bissell MJ: The perivascular niche regulates breast tumour dormancy. Nat Cell Biol 2013, 15:807-817

41. Syn WK, Choi SS, Liaskou E, Karaca GF, Agboola KM, Oo YH, Mi Z, Pereira TA, Zdanowicz M, Malladi P, Chen Y, Moylan C, Jung Y, Bhattacharya SD, Teaberry V, Omenetti A, Abdelmalek MF, Guy CD, Adams DH, Kuo PC, Michelotti GA, Whitington PF, Diehl AM: Osteopontin is induced by hedgehog pathway activation and promotes fibrosis progression in nonalcoholic steatohepatitis. Hepatology 2011, 53:106-115

42. Pritchett J, Harvey E, Athwal V, Berry A, Rowe C, Oakley F, Moles A, Mann DA, Bobola N, Sharrocks AD, Thomson BJ, Zaitoun AM,
Irving WL, Guha IN, Hanley NA, Hanley KP: Osteopontin is a novel downstream target of SOX9 with diagnostic implications for progression of liver fibrosis in humans. Hepatology 2012, 56:1108-1116

43. Syn WK, Agboola KM, Swiderska M, Michelotti GA, Liaskou E, Pang H, Xie G, Philips G, Chan IS, Karaca GF, Pereira Tde A, Chen Y, Mi Z, Kuo PC, Choi SS, Guy CD, Abdelmalek MF, Diehl AM: NKT-associated hedgehog and osteopontin drive fibrogenesis in non-alcoholic fatty liver disease. Gut 2012, 61: $1323-1329$

44. El-Karef A, Yoshida T, Gabazza EC, Nishioka T, Inada H, Sakakura T, Imanaka-Yoshida K: Deficiency of tenascin-C attenuates liver fibrosis in immune-mediated chronic hepatitis in mice. J Pathol 2007, 211:86-94

45. Camino AM, Atorrasagasti C, Maccio D, Prada F, Salvatierra E, Rizzo M, Alaniz L, Aquino JB, Podhajcer OL, Silva M, Mazzolini G: Adenovirus-mediated inhibition of SPARC attenuates liver fibrosis in rats. J Gene Med 2008, 10:993-1004

46. Atorrasagasti C, Aquino JB, Hofman L, Alaniz L, Malvicini M, Garcia M, Benedetti L, Friedman SL, Podhajcer O, Mazzolini G: SPARC downregulation attenuates the profibrogenic response of hepatic stellate cells induced by TGF- $\beta 1$ and PDGF. Am J Physiol Gastrointest Liver Physiol 2011, 300:G739-G748

47. Atorrasagasti C, Peixoto E, Aquino JB, Kippes N, Malvicini M, Alaniz L, Garcia M, Piccioni F, Fiore EJ, Bayo J, Bataller R, Guruceaga E, Corrales F, Podhajcer O, Mazzolini G: Lack of the matricellular protein SPARC (secreted protein, acidic and rich in cysteine) attenuates liver fibrogenesis in mice. PLoS One 2013, 8: e54962

48. McAllister SS, Gifford AM, Greiner AL, Kelleher SP, Saelzler MP, Ince TA, Reinhardt F, Harris LN, Hylander BL, Repasky EA, Weinberg RA: Systemic endocrine instigation of indolent tumor growth requires osteopontin. Cell 2008, 133:994-1005

49. Oskarsson T, Acharyya S, Zhang XH, Vanharanta S, Tavazoie SF, Morris PG, Downey RJ, Manova-Todorova K, Brogi E, Massagué J: Breast cancer cells produce tenascin $\mathrm{C}$ as a metastatic niche component to colonize the lungs. Nat Med 2011, 17:867-874

50. Wang Z, Ouyang G: Periostin: a bridge between cancer stem cells and their metastatic niche. Cell Stem Cell 2012, 10:111-112 